\title{
The analysis of stochastic dependence in determining a decision on setting up a firm in Poland - survey results
}

\begin{abstract}
In the literature on the subject, entrepreneurship is generally equated with a process aimed at enabling a given individual to set up and manage his/her own enterprise. The process itself is affected by a number of factors, both economic and non-economic. This article is aimed at analysing the stochastic dependence of factors determining one's decision on setting up his/her firm in Poland. The determinants will be verified on the basis of empirical material collected in the course of a questionnaire survey conducted by the author.
\end{abstract}

Keywords: entrepreneurship, labour market, post-socialist countries

Introduction

People have, since time immemorial, had to cope with a number of difficulties in order to survive, e.g. continuing changes in living conditions stemming from environmental transformation (Bygrave and Zachwakis, 2010). Only the most resourceful, intelligent and enterprising individuals able to seize opportunities and adjust to the environment could provide themselves with a proper standard of living (Darwin, 1979). Humans had to meet their basic needs, i.e. provide food, drink and a sense of security and, as a result, they became the most civilised, resourceful and enterprising species (Lipski, 2003).

With time, humans began to occupy a crucial role on the globe. They were not just one of many species any more, but started to manage, govern, use and adjust the natural environment to produce the best results possible. They could not do so if they were not creative and inventive and were they not to have developed entrepreneurial spirit (to provide themselves with adequate living conditions and to satisfy their needs).

Entrepreneurial attitudes and behaviour had already been noticed in ancient times, e.g. in Greece. They were reflected mainly in the mass colonisation of the Mediterranean coast; the creation of agricultural households specialising in the cultivation of wheat and barley or animal breeding; the issuance of coins; and, finally, in literary output. These were aimed at the development of trade exchange in order to satisfy social needs and contribute to the economic growth of the state.

New markets were created in coastal villages, shipping transport developed and money became common, while entrepreneurship was reflected in the teachings of Greek philosophers. Plato, the follower of Socrates, called for the creation of an ideal state in which the outstanding and most resourceful individuals should occupy managerial positions whereas others should work in agriculture, craft, trade or the army in order to meet their needs and achieve certain objectives. Xenophon, also a follower of 
Socrates, suggested how to make substantial profit from agricultural farming in his work entitled Ekonomik. Not only did he drop hints as to how to educate future rulers to decide what and how to produce, he also discussed ways to cultivate particular types of soils and plants in order to improve crop yields (Stankiewicz, 2007). Still another Greek philosopher, Aristotle, discussed the theoretical correlations found in the course of trade exchange based mainly on willingness to meet merchants' needs and to allow them to grow rich.

The essence of entrepreneurship was also referred to by the ancient thinker, Katon. He laid the foundations for agricultural economics in his dissertation entitled About a farm household (Stankiewicz, 2007). Not only did he describe where it was best to establish a plantation and how to manage it, but also kept accurate economic account of the cultivation of two alternative plants, i.e. olives and vines. He encouraged landowners to enter continuing education and to take an active part in managing a farm.

In the Middle Ages, entrepreneurial actions and processes were obstructed. Admittedly, trade exchange was subject to development, as first banking institutions and then merchant associations were established, yet technological progress in agriculture and industry was extremely slow and determined not only by environmental changes. Economic thought evolved mainly on the grounds of the teaching of the Church, which had a great effect on people at that time. According to the Church, people should be righteous, avoid temptation and satisfy only their basic needs, as well as to focus on prayer and reflection concerning the future of mankind. In this way, Catholics were not inspired to take actions promoting an active and creative life.

Socio-economic transformation, and hence the further development of entrepreneurship, was observed in the $16^{\text {th }}$ and $17^{\text {th }}$ centuries after the stagnation of the Middle Ages. This was largely determined by the geographical discovery of new territories and the establishment of sea lanes. ${ }^{1}$ This, in turn, led to an increase in the number of business entities engaged in sea transport, while trading exchange grew in importance. It was no longer only local, but had acquired an international dimension. The result was that agriculture and industry were subject to dynamic growth. People sought ways of improving production processes, mainly via inventions and their new applications, while the successful management of resources and their efficient use was to enable them to think and act in an entrepreneurial and creative way.

The $18^{\text {th }}$ and $19^{\text {th }}$ centuries were also a time of the continual development of entrepreneurship and witnessed the growing social importance of the entrepreneur. Britain's expansive economy became a sort of indicator, as well as a determinant of global production and trade. The invention of the steam engine revolutionised production engineering, which allowed constructors to use innovations in such processes. The wars that England waged with its neighbours, namely Holland and France, intensified industrial production even more and thus proved its power. The image of the entrepreneur was created; namely, as a person who takes independent actions, organises production, introduces innovations, invests his/her own capital assets and takes risk (Bygrave and Zachwakis, 2010). It was at this point that the entrepreneur became an

1 e.g. the discovery of America by Christopher Columbus; Vasco da Gama's sea voyage to India; and Ferdinand Magellan's sea voyage round the world. 
important figure in the hierarchy of social values as he/she had capital, created new jobs, employed workers and took advantage of technical progress.

The events that took place in the $20^{\text {th }}$ century, and particularly the consequences of World War I and World War II, had an even greater influence on social entrepreneurship. Citizens of countries participating in the two world wars not only had to survive during the armed conflicts, but also subsequently to reconstruct their homelands. Only initiative, resourcefulness and self-confidence enabled the strongest individuals both to function and to survive.

Post-war stabilisation inspired people to create a new concept of entrepreneurship. On the basis of European states - reviving and undergoing economic transformation and the developing economies of Japan and America, a number of new concepts and theories relating to this issue were formulated. Unfortunately, none of them has been explicitly defined or chosen as universal. Hence, it is beyond any doubt that entrepreneurship is one of the most 'mysterious' issues in economic theory (Ripsas, 1998).

Nowadays, entrepreneurship is equated with a process aimed at enabling an individual to set up and manage a firm. The process is affected by a number of economic and non-economic factors. Bearing this in mind, it is a sound process to carry out an analysis of stochastic dependence in the determination of the entrepreneurial process.

The survey results

The empirical material used for the analysis of stochastic dependence in determining entrepreneurship decisions was the declarations made by respondents to our questionnaire survey. This survey examined the determinants of entrepreneurial behaviour displayed by young people living in the Polish countryside. It was conducted at the turn of 2008 and 2009 on a representative sample of 534 people aged 15-24.

In order to verify the correlation between the entrepreneurship displayed by young people and selected variables, Cramer's V was employed, as the variables were nonmeasurable. It should be stated that this coefficient was chosen to determine how strong was the correlation between variables (measures expressed on a nominal scale). Cramer's V takes values in the range (0-1). In the case of stochastic independence, it equals zero. If functional dependence is $V=1$, there is no correlation. The value of Cramer's V does not depend on the number of columns and lines in the associative table, as a result of which it has a certain advantage over another popular coefficient, namely T-Czuprow's.

Cramer's V was calculated in accordance with the following formula:

$\mathrm{V}=$

$$
\sqrt{\frac{\chi^{2}}{N \min ((w-1),(k-1))}}
$$

where:

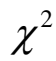


- calculated in accordance with the formula below;

$\mathrm{k}$ - number of columns;

$\mathrm{w}$ - number of lines;

$\mathrm{N}$ - total size

and where min. is the slightest difference $\mathrm{w}-1, \mathrm{k}-1$.

In order to determine stochastic dependence with the use of Cramer's V, the collected empirical material was arranged in correlation tables. Particular types of entrepreneurship were presented in columns while selected variables were included in the lines.

To examine the importance of the dependence, the author has used an independence test that allows verification where a given two qualities are established as independent of each other. Hence, an independence table was constructed which, once completed, became the matrix of empirical size. Then, this matrix and the matrix of theoretical size (calculated on the assumption that the qualities are independent) were superimposed on each other and compared with the use of chi-square statistics. This enabled us to state that the hypothesis about the independence of the qualities can be rejected as there are considerable differences between empirical and theoretical size.

The chi-square statistic

$\chi^{2}$

was calculated in accordance with the following formula:

$$
\chi^{2}=\sum_{i=1}^{w} \sum_{j=1}^{k} \frac{\left(n_{i j}-\hat{n}_{i j}\right)}{\hat{n}_{i j}}=\sum_{i=1}^{w} \sum_{j=1}^{k}\left(\frac{\hat{n}_{i j}^{2}}{\hat{n}_{i j}}\right)-N
$$

In order to determine theoretical value $\mathrm{n}_{\mathrm{ij}}$, the following formula was employed:

$$
\hat{n}_{i j}=\frac{n_{i .} \cdot n_{. j}}{N}
$$

(Paradysz, 1996)

The following variables were subject to in-depth analysis:

- gender

age

- education

- number of household members

- number of unemployed household members

- number of brothers and/or sisters

- population in the place of residence

- parent's education and occupational activity

- access to latest technology, science and communications. 
Table 1 shows the values of Cramer's $\mathrm{V}$ and the chi-square test employed for defining the dependence of propensity to set up a firm upon the particular variables determining the entrepreneurial process. Furthermore, the importance of particular factors affecting the decision in question was also subject to analysis.

Table 1 - Cramer's V and chi-square test employed for establishing the dependence of propensity to set up an enterprise upon particular variables determining the process

\begin{tabular}{|l|c|c|}
\hline & Cramer's V & Chi-square test \\
\hline Gender & 0.1552394 & 23.96321 \\
\hline Education & 0.1942731 & 32.76007 \\
\hline Age & 0.2004475 & 34.87556 \\
\hline No. of household members & 0.2252016 & 44.02126 \\
\hline No. of brothers and/or sisters & 0.2008204 & 35.00544 \\
\hline No. of unemployed household members & 0.1640408 & 23.14208 \\
\hline Mother's occupational activity & 0.218384 & 46.87366 \\
\hline Father's occupational activity & 0.1734567 & 24.8763 \\
\hline Occupational activity & 0.2563853 & 57.05662 \\
\hline Access to latest technology and communication & 0.1591374 & 21.98185 \\
\hline
\end{tabular}

Source: own calculations based on the survey.

\section{Gender}

Having examined the correlation between gender and willingness to set up a firm, it should be stated that that there is a significant stochastic dependence.

\section{Age}

Having investigated the willingness to establish one's own enterprise in the context of the age of the respondent in question, it can be stated that there is a stochastic dependence. Cramer's V suggests that there is a noticeable correlation between tendency to start business activity and the age of young people living in the countryside.

\section{Education}

Thanks to the independent chi-square test used for seeking correlation between willingness to set up a firm and age, it was determined that such a relationship exists. The stochastic dependence, analysed on the basis of Cramer's V (0.194), is significant, yet weak. 


\section{Number of household members}

On the basis of statistical estimation, it can be stated that willingness to start a business depends, at the $95 \%$ confidence level, on the number of household members. Cramer's V amounts to 0.261 and, hence, the correlation is significant.

\section{Number of brothers and/or sisters}

Significance testing suggests that a decision about setting up a firm depends on the number of brothers and/or sisters in the family of a given respondent. Cramer's V amounts to 0.200 and, thus, the correlation is quite strong.

\section{Parents' occupational activity}

This is another factor determining the decision on starting a business. Mother's and father's occupational activity were examined separately. It can be stated that there is a correlation between parental activity and one's willingness to establish his/her own firm. Cramer's V suggests that mother's occupational activity, however, has a greater effect on respondents' level of entrepreneurship than father's activity ( 0.218 and 0.173 respectively).

\section{Occupational activity}

This is a variable that also affects respondents' decisions on starting a business. However, the statistical correlation between the aforementioned variables is noticeable, yet weak.

\section{Access to latest technology and communications}

Having investigated the correlation between one's willingness to establish an enterprise and level of access to the latest technology and communications facilities, it can be stated, on the basis of chi-square statistics, that the correlation is significant. Cramer's V suggests that stochastic dependence is noticeable, although weak.

\section{Earnings}

Apart from the aforementioned variables, the author also examined whether the prospects for higher earnings determined decisions on starting a business. On the basis of statistical estimation, it can be stated that there is a large correlation between these variables. Cramer's V, reflecting the strength of the stochastic dependence, suggests that the correlation between these variables is significant and strong $(0.321)$. This is also proven by the coefficient of determination, which indicates that the higher income associated with managing one's own business (as opposed to hiring out one's own labour), affects the decisions made by $10.3 \%$ of respondents about setting up a firm.

In the light of these declarations, it seems interesting to analyse the factors which determined positive answers to the following question: does setting up a firm provide one with the possibility of generating higher income than hiring out one's own labour? We might mention the following factors as being those which are most likely to exert 
the most profound effect on prospects for higher earnings in one's own firm (as opposed to hiring out one's own labour):

- education

a age

- number of unemployed household members

- parental occupational activity

- and risk-taking propensity (see Table 2).

Table 2 - Cramer's V and chi-square test employed for determining the dependence of prospects for higher earnings (once managing a firm) upon certain variables determining the process

\begin{tabular}{|l|c|c|}
\hline & Cramer's V & Chi-square test \\
\hline Education & 0.18969 & 31.23246 \\
\hline Age & 0.20975 & 38.18782 \\
\hline No. of unemployed household members & 0.14692 & 18.56458 \\
\hline Mother's education & 0.16425 & 23.41795 \\
\hline Father's education & 0.16550 & 23.77338 \\
\hline Area of holding & 0.41527 & 146.9241 \\
\hline Risk-taking propensity & 0.13740 & 16.31160 \\
\hline
\end{tabular}

Source: own calculations based on the survey.

\section{Education}

On the basis of statistical estimation, it was found that the higher one's education, the higher the income (i.e. associated with managing a business), as suggested by the $95 \%$ confidence level. The results suggest that the correlation is noticeable, yet rather weak. Furthermore, the coefficients of determination indicate that the level of education affected the decisions made by $3.5 \%$ of respondents on setting up a firm for financial reasons.

Age

There is a correlation between higher income and age. Cramer's V reached 0.209, which suggests that there is a significant, yet weak, correlation between establishing a firm for financial reasons and age. Furthermore, the coefficient of determination reflects that setting up an enterprise in order to earn greater income depends on age in the case of over $4 \%$ of respondents.

Number of unemployed household members

This is another variable exerting an influence on the correlation under analysis. It is noticeable, yet weak. 


\section{Parents' education}

Having examined the stochastic dependence of decisions on establishing an enterprise to generate higher income (compared to hiring out one's own labour) upon the level of the education of the mother of the respondent, it should be stated that it is significant. As for father's education - the correlation is also noticeable. The coefficients of determination suggested that the occupational activity of the mother determined the relationship under consideration in $2.6 \%$ of cases, whereas the occupational activity of the father was a determining factor in $2.4 \%$ cases.

\section{Parental occupational activity}

Having investigated the correlation between higher earnings (the factor that determines decisions on starting a business) and parental occupational activity, it can be stated that it is noticeable - both in the case of the occupational activity of the mother and of the father. Nevertheless, the correlation is weak and amounts to respectively 0.134 and 0.165 for the occupational activity of the mother and father.

\section{Risk-taking propensity}

Employing independent chi-square testing for seeking the correlation between one's decision about setting up a firm to generate higher income and the risk-taking propensity declared by young people living in the countryside, it can be stated that there is a relationship between these variables. However, it is weak, as proven by a low value of Cramer's V (0.13740).

\section{Conclusion}

On the basis of the survey results, it should be stated that decisions on establishing an enterprise are determined by a number of economic and non-economic factors. As for the former, one can mention the professional activity displayed by the respondents and their source of permanent income. Furthermore, it is interesting that respondents are inclined to believe that setting up a firm entails higher income, which is another economic factor determining the entrepreneurial process.

On the other hand, non-economic factors also have a great effect on decisions made by young people in the countryside about starting business activity. Just as in the case of entrepreneurial attitudes, variables such as gender, age, education and the number of household members, as well as the number of brothers and/or sisters in the family, are factors which affect this decision. In contrast, parental education and professional activity exert only minor influence.

Summing up, it should be noticed that entrepreneurship is determined by economic and non-economic factors to a varying degree. The effectiveness of the factors referred to in this article, and which are important from the statistical point of view, depends mainly on certain characteristics displayed by the group under analysis. Economic factors may exert a profound influence on the development of entrepreneurial processes and the attitudes of young people living in the countryside, but it should be emphasised that the survey results suggest that these factors do not fully and satisfactorily account for the level of entrepreneurial behaviour displayed by respondents. Therefore, non- 
economic factors, particularly those which are subjective in nature, are likely to occupy a greater and greater role in the popularisation of entrepreneurial attitudes and processes among young people living in the countryside.

\section{References}

Bygrave W. D and A. Zacharakis (2010) Entrepreneurship John Wiley and Sons, pp. 4-9; 531-550.

Darwin, C On the Origin of Species Random House Value Publishing: New York, 1979, pp. 158-162.

Lipski, S (2003) 'Przedsiębiorczość, postawa, talent' in: J. Merski and K. Piotrkowski (Eds.) Przedsiębiorczość mlodzieży, szanse, bariery, perspektywy WSE: Warszawa, pp. 39-40.

Paradysz, J (1996) Statystyka w przyktadach i zadaniach Wyd. Akademii Ekonomicznej w Poznaniu: Poznań, p. 126.

Ripsas, S (1998) 'Towards an Interdisciplinary Theory of Entrepreneurship' Small Business Economics 10(3): 103.

Stankiewicz, W (2007) Historia myśli ekonomicznej PWE: Warszawa, pp. 38-40. 